\title{
OBITUARIES
}

\section{Dr. Edward Kidson, O.B.E.}

$\mathrm{D}^{\mathrm{n}}$ R. EDIVARD KIDSON, director of the Mreteorological Office, Wellington, Now Zealand, died suddenly on June 12 at the early age of fifty-seven years.

Dr. Kidson belonged to a well-known Nelson and Christchurch family, but was born at Bilston, Staffordshire, on March 12, 1882. He received his school and university education in New Zealand, graduating at the University of New Zealand with first-class honours in physics in 1904. His first post was that of assistant observer at the Magnetic Observatory, Christehurch, which led to his joining the staff of the Department of Terrestrial Magnetism of the Carnegie Institution of Washington in 1908. Before the Great War he was engaged on magnetic surveys in South America, Newfoundland and Australia, and he spent six months as magnetic observer on the magnetic survey ship Carnegie belonging to the Carnegie Institution.

During 1915-1919 he was on active sorvice in the Meteorological Section of the Royal Engineers with the Salonika Force. He was mentioned in dispatehes and made O.B.E. for his war service. After the War he returned to the Carnegie Institution and was given charge of its Magnetic Observatory at Watheroo, Western Australia. Kidson remained at Watheroo from 1919 until 1921, when he joined the Meteorological Service of the Australian Commonwealth as assistant director.

In 1921 Kidson returned to New Zealand on being appointed director of the Meteorological Office, Wellington. The Meteorological Service of New Zealand when Kidson took charge was in a very unsatisfactory state and the total staff numbered only five. With characteristic energy he set to work to build up a service based on modern scientific lines. Kidson's travels had kept him in touch with meteoro. logical progress in America and Europe; he was a man of science and appreciated the work of the Norwegian school of meteorologists. He visited Bergen in 1931 and 1935 and, aided by one of Dr. Bjerknes's assistants, who stayed a fow months in New Zealand on his return from the Antarctic, ho introduced the Norwegian ideas into the work of his service and in this way broke new ground in the study of meteorology in the southern hemisphere. He was fortunate in his choice of scientific assistants, and with their aid built up a meteorological service, consisting of forty-five members, which compares favourably from a scientific point of view with the meteorological service of any other country.

Kidson's own scientific work, with the exception of the reports he prepared on terrestrial magnetism while on the staff of the Carnegie Institution, was devoted almost entirely to meteorology. He wrote extensively on the climate of New Zealand, and was interested in the investigation of the upper atmosphere. He published papers on weather forecasting and the theory of tornadoes. He was particularly interested in Antaretic meteorology; his chief published work was a thorough discussion of the meteorological records of Shackleton's first expedition (1907-9) and at the time of his death he was on the point of completing a compilation and discussion of the meteorological data obtained on Mawson's later expeditions.

Kidson's sound scientific knowledge, coupled with a wide and sane outlook on international meteoro. logical problems, was unsurpassed in the southern hemisphere, and his early death just at the time when such qualities are especially required is a real tragedy.

G. C. Surrson.

\section{Dr. C. H. Mayo}

Dr. C. H. MIAyo, who died on Mray 28, was one of the greatest of contemporary American surgeons. During his active career of nearly fifty years, he was associated with his elder brother, Dr. W. J. Mayo, in founding and fostering the Clinic in Rochester, Minnesota, which bears their name. In their life. time, this has expanded rapidly until now it is a huge centre of medical and scientific effort, an expansion the more remarkable because of the small size of the town and its distance from main roads and railways.

Dr. Mayo's scientific work cannot be considered apart from the development of the Clinic. At an early date the brothers determined to devote the profits of the enterprise to the furtherance of medical education and research, and gradually brought together a team of workers which included clinicians, experts in preclinical subjects and, notably, experts in the related sciences of biochemistry and biophysics. Thus their object has como to bo the intensive study of all aspects of disease, as well as its treatment. This type of organization was an admirable background for Dr. Mayo's substantial contributions to the surgery of the thyroid gland. He was one of the earliest to operato for thyrotoxicosis, and did much to eliminate the technical difficulties associated with this procedure. Later he was able to utilize the discovery by his colleagues, H. S. Plummer and Boothby, that the administration of iodine reduced the dangers of operation, and to add and adopt further refinements in pre-operative and postoperative care, and in surgical technique. His work on transplantation of the ureters to the colon in cases of ectopia vesicre was also outstanding, and in his hands this was a safe and satisfactory operation. He approached the problem as a biologist, and in inducing the rectum to function as a cloaca he displayed great technical ingenuity and a sturdy respect for the conservation of renal function.

Dr. Mayo was essentially a general surgeon, and his nimble mind attacked and solved many diverse 